\title{
Population genetics of the bigeye thresher shark Alopias superciliosus in the Atlantic and Indian Oceans: implications for conservation
}

\author{
Millke Jasmine Arminini Morales • Fernando Fernandes Mendonça • \\ Carolina Oliveira Magalhães - Claudio Oliveira - Rui Coelho - Miguel Neves Santos • \\ Vanessa Paes Cruz • Andrew Piercy • George Burgess • Fabio Vieira Hazin • \\ Fausto Foresti
}

Received: 11 July 2017 / Accepted: 20 July 2018/Published online: 25 July 2018

(C) Springer Nature Switzerland AG 2018

\begin{abstract}
Population structure and genetic connectivity are pivotal contributions to the establishment of conservation strategies for fisheries management, in particular for highly migratory species that are affected by commercial fisheries. This study used partial sequences of mitochondrial DNA control region to determine the genetic structure of the bigeye thresher shark Alopias superciliosus in the Atlantic and Indian Oceans. A total of 858 base pairs of mtDNA CR from 228 individuals were analyzed. The
\end{abstract}

Electronic supplementary material The online version of this article (https://doi.org/10.1007/s11160-018-9531-4) contains supplementary material, which is available to authorized users.

M. J. A. Morales · C. O. Magalhães · C. Oliveira .

V. P. Cruz · F. Foresti

Laboratório de Biologia e Genética de Peixes, Instituto de Biociências de Botucatu, Universidade Estadual Paulista

(UNESP), Botucatu, São Paulo, Brazil

F. F. Mendonça $(\bowtie)$

Laboratório de Genética Pesqueira e Conservação, Instituto do Mar, Universidade Federal de São Paulo (UNIFESP), R. Carvalho de Mendonça, 144, CEP 11070-100 Santos, São Paulo, Brazil

e-mail: fernando.mendonca@unifesp.br

R. Coelho $\cdot$ M. N. Santos

Instituto Português do Mar e da Atmosfera (IPMA),

Olhão, Portugal resulting nucleotide diversity $(\pi)$ was $0.0011 \pm 0.0008$ and the haplotype diversity (h) was $0.127 \pm 0.030$. These are the lowest diversities registered in elasmobranchs with this genetic marker. Two genetically distinct lineages were identified, one of them represented by $3.9 \%$ of the analyzed individuals and none restricted to any particular area. Simulated scenarios of population structure, tested with AMOVA and pairwise $\Phi_{\mathrm{ST}}$ did not result in significant values indicating high connectivity among all sampled groups. The absence of population structure, even between Atlantic and Indian Oceans, corroborates the high dispersal ability of this species. The low genetic diversity detected in this species and

R. Coelho

Centro de Ciências do Mar (CCMAR), Universidade do Algarve, Faro, Portugal

A. Piercy

Lake Nona Campus, Valencia College, Orlando, FL, USA

G. Burgess

Florida Museum of Natural History, Florida Program for Shark Research, University of Florida, Gainesville, FL, USA

\section{F. V. Hazin}

Departamento de Pesca e Aquicultura, Universidade Federal Rural de Pernambuco (UFRPE), Recife,

Pernambuco, Brazil 
the identification of two historical lineages occurring in sympatry, one represented by a very small number of individuals, should be considered in the conservation efforts and management plans of $A$. superciliosus.

Keywords Population genetics - Conservation genetics · Fisheries management · Alopiidae · Mitochondrial DNA

\section{Introduction}

Continuous fishing pressure, both targeted and as bycatch, has caused population declines in several species of elasmobranchs in some regions of the planet. In general, management and conservation strategies for elasmobranchs, particularly oceanic pelagic species, have been hampered by the lack of information on population structure, species-specific catch data, and scarcity of reports on the distribution and status of stocks throughout the species' range (Camhi et al. 2009).

Several methods have been used to identify fish stocks and geographic delimitation of their distributions, including tagging, morphological measurements, and genetic evaluations (e.g., Dudgeon et al. 2012). Studies using genetic tools have demonstrated some degree of population structure in highly migratory marine species at different scales in the oceans (e.g. André et al. 2011; O'Leary et al. 2015; Camargo et al. 2016; Veríssimo et al. 2017), despite most oceans not having obvious physical or environmental barriers to prevent migration and dispersion of fish (Waples 1998).

The bigeye thresher, Alopias superciliosus, has a global distribution, inhabiting tropical and subtropical regions, coastal areas, and especially the open ocean in pelagic zones (Compagno 2001; Fernandez-Carvalho et al. 2015a). This species has been described as having a long life cycle with a maximum age of 25 years (Fernandez-Carvalho et al. 2015b) and late sexual maturity, 9-10 years for males and 13 years for females (Liu et al. 1998). This species is an aplacental viviparous shark with intrauterine oophagy usually bearing only two embryos per litter-one per uterus (although cases of up to four embryos may occur); the gestation period is about 12 months, resulting in an extremely low fecundity (Chen et al. 1997; Compagno
2001). Given these characteristics, the annual population growth rate is very low (0.002) compared to other sharks (Chen et al. 1997; Camhi et al. 2009), giving this species a low resilience from fisheries impacts (Simpfendorfer et al. 2008; Cortés et al. 2010).

Alopias superciliosus is commonly captured as bycatch by pelagic longline boats targeting tuna and swordfish and has a moderate to high mortality in this type of fishing (Camhi et al. 2009; Coelho et al. 2012). Although there is still a need for assessments throughout its distribution range, this species has been showing strong signs of vulnerability to fishing pressure, evidenced by a general decline in catches in recent years (Camhi et al. 2008; ICCAT 2013). Alopias superciliosus is listed in the International Union for Conservation of Nature and Natural Resources (IUCN) red list as "Vulnerable" in the eastern Central Pacific region and the western IndoPacific, "Endangered" in the Northwest and Western Central Atlantic, and "Near Threatened" in the southwest Atlantic (Amorim et al. 2009). In 2016, it was listed in Appendix II of CITES (Convention on International Trade in Endangered Species of Wild Fauna and Flora).

The study of population genetics is an essential component for the characterization of genetic diversity, identifying different evolutionary units and their distribution, delineation of genetic stocks, gene flow, and inferences to conservation. Given the present lack of knowledge of population genetics for the bigeye thresher, this study aimed to evaluate these parameters using DNA sequences from the mitochondrial control region of A. superciliosus from the Indian and Atlantic Oceans.

\section{Materials and methods}

Sampling and laboratory procedures

Samples of A. superciliosus, all adults, were collected by onboard fishery observers from: the Portuguese Institute for the Ocean and Atmosphere (IPMA) on commercial pelagic long-line vessels in several regions of the Atlantic and Indian Oceans; researchers from São Paulo State University and Federal Rural University of Pernambuco, along the Brazilian coast; from the east coast of Florida, by the Florida Program 
for Shark Research, University of Florida. The site locations were registered by Global Positioning System (GPS) at the long-line deployment points. Tissue samples, including small pieces of muscle or fin fragments $\left(<1 \mathrm{~cm}^{3}\right)$, were collected during the normal fishing operations of the vessels and subsequently frozen in $95 \%$ ethanol.

Specimens $(\mathrm{N}=228)$ were sampled and organized in eight groups according to their geographical locations, including 74 samples from the Northwest Atlantic (ANE, midpoint location at lat. $16^{\circ} 30^{\prime} \mathrm{N} /$ $\left.26^{\circ} 34^{\prime} \mathrm{W}\right) ; 22$ samples from the Western Equatorial Atlantic-1 (EE1, midpoint location $2^{\circ} 30^{\prime} \mathrm{S} /$ $\left.16^{\circ} 20^{\prime} \mathrm{W}\right) ; 51$ samples from the Western Equatorial Atlantic-2 (EE2, midpoint location $2^{\circ} 30^{\prime} \mathrm{S} / 6^{\circ} 50^{\prime} \mathrm{W}$ ); 26 samples from the Southeast Atlantic (ASE, midpoint location $17^{\circ} 10^{\prime} \mathrm{S} / 0^{\circ} 30^{\prime} \mathrm{W}$ ); 3 samples from the South Atlantic (AS, midpoint location $37^{\circ} 10^{\prime} \mathrm{S} /$ $\left.12^{\circ} 50^{\prime} \mathrm{W}\right) ; 19$ samples from the West Equatorial (EW, midpoint location $2^{\circ} 40^{\prime} \mathrm{S} / 32^{\circ} 20^{\prime} \mathrm{W}$ ); 13 samples from the Southwest Atlantic (ASW, midpoint location $\left.25^{\circ} 20^{\prime} \mathrm{S} / 35^{\circ} 50^{\prime} \mathrm{W}\right) ; 3$ samples from the Northwest Atlantic (ANW, near the east coast of Florida, USA). Also, 16 samples were collected from the Southwest Indian Ocean (ISW, oceanic waters between South Africa and Madagascar) (Fig. 1).
Total DNA was extracted using a "glass-fiber" protocol (Ivanova et al. 2006). The mitochondrial DNA control region (mtDNA CR) was amplified by polymerase chain reaction (PCR) using primer Pro-L (5'-AGG GRA AGG AGG GTC AAA CT- $3^{\prime}$ ) and primer 282 (5'-AAG GCT AGG ACC AAA CCT-3'), developed by Keeney and Heist (2006). Amplifications were carried out in $12.5 \mu \mathrm{l}$ reactions containing $1 \mathrm{X}$ Taq DNA polymerase PCR buffer (Tris-HCl $20 \mathrm{mM} \mathrm{pH} 8.4$ and $\mathrm{KCl} 50 \mathrm{mM}$ ), $0.2 \mathrm{mM}$ for each dNTPs, $1.5 \mu \mathrm{M}$ of $\mathrm{MgCl}_{2}, 1 \mu \mathrm{l}$ of DNA template and 2 units of Taq DNA Polymerase (Invitrogen). The cycling conditions were $94{ }^{\circ} \mathrm{C} 5 \mathrm{~min}, 35$ cycles of $94{ }^{\circ} \mathrm{C} 1 \mathrm{~min}, 58{ }^{\circ} \mathrm{C} 30 \mathrm{~s}$, and $72{ }^{\circ} \mathrm{C} 1 \mathrm{~min}$, with a final extension at $72{ }^{\circ} \mathrm{C}$ for $7 \mathrm{~min}$. The nucleotide sequences were obtained using two internal forward primers, F 5'-CTC CCA AAG CCA AGA TTC TG-3' (Mendonça et al. 2009) and AloS-F 5'-CCT CTA GTT CCC TTT AAT GG-3' (present study), and the protocols of the BigDye ${ }^{\circledR}$ Terminator v3.1 Cycle Sequencing Kit (Thermo Fischer Scientific Inc.) on an ABI PRISM_3130 Genetic Analyzer (Thermo Fischer Scientific Inc.).

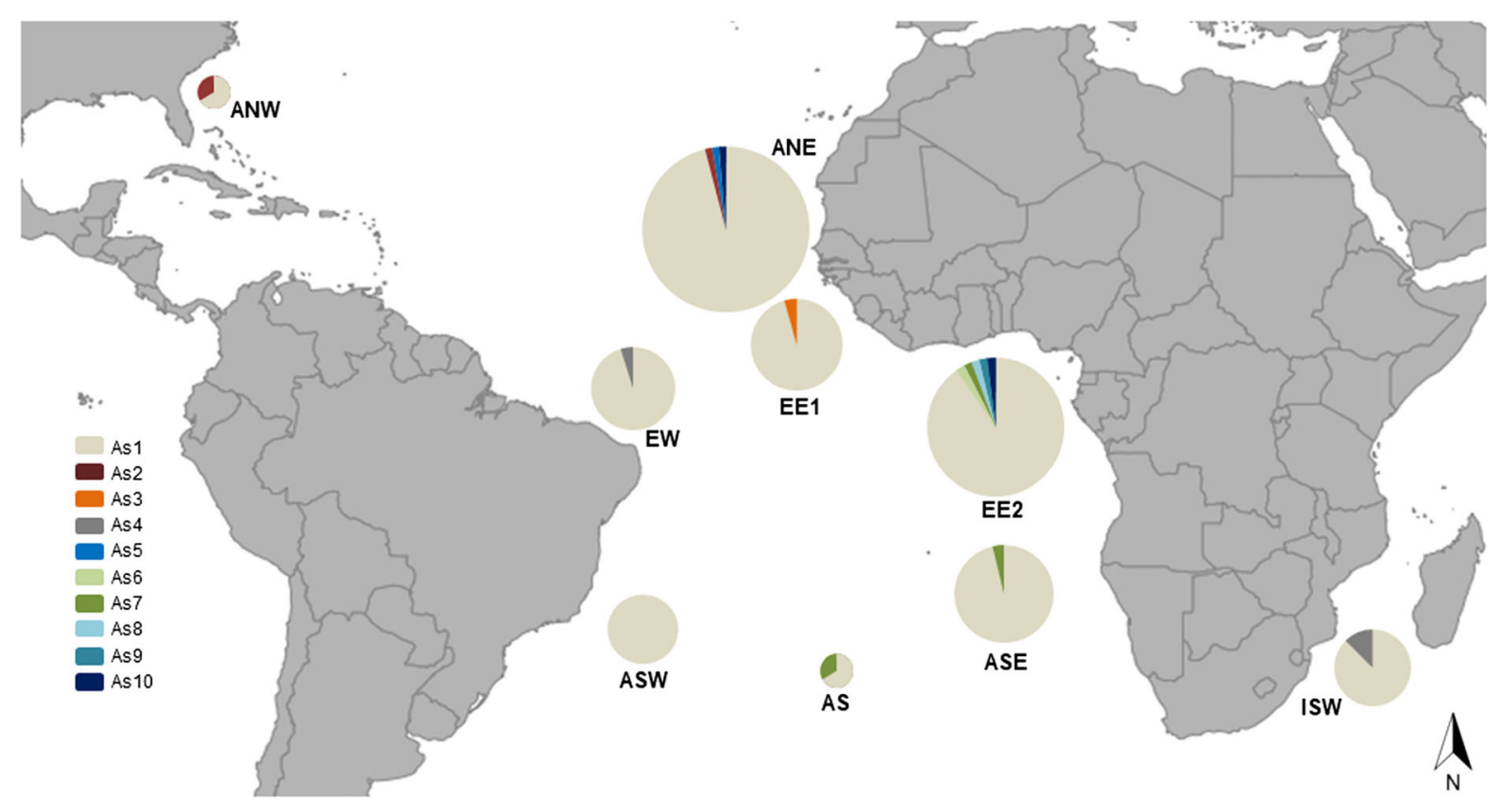

Fig. 1 Distribution map of the sampling areas and characterization of the haplotypes and their frequencies found in each location. Circle size is proportional of sample size per location, and colors refer to different haplotypes as indicated in the left of the figure 
Population genetic analyses

The forward sequences were assembled and edited using Geneious 4.8.5 (Kearse et al. 2012) and aligned using the Muscle algorithm implemented within Geneious 4.8.5. Estimates of genetic diversity represent a valuable resource for biodiversity assessments and are increasingly used to guide conservation and management programs. The number and frequency of haplotypes, polymorphic sites, haplotype diversity $(h)$, nucleotide diversity $(\pi)$, and transitions and transversions were calculated using ARLEQUIN version 3.5 (Excoffier and Lischer 2010).

To analyze the relationship between the haplotypes and the geographic distribution of individuals from each of these haplotypes, we built the haplotype network based on the statistical parsimony criteria calculated by the Median-joining algorithm using the Network 4.6 program (Bandelt et al. 1999). The genetic distance between the lineages and the Neighbor-Joining tree of haplotypes was calculated using the MEGA 6.0 (Tamura et al. 2013) software, using the Tamura-Nei evolutionary model (Tamura and Nei 1993). This allowed us to reconstruct the phylogenetic tree of haplotypes from evolutionary distance data. A sequence of the mtDNA control region of A. superciliosus available at GenBank (Accession No. KC757415) was included in haplotype tree. Sequences of three other species of lamniforms, Alopias pelagicus, Alopias vulpinus and Isurus oxyrinchus (GenBank Accession Nos. KF412639, MF374733.1 and NC_022691, respectively) were adopted as outgroup.

We used pair-wise estimates of fixation index $\left(\Phi_{\mathrm{ST}}\right)$, an $F_{\mathrm{ST}}$ analogue for DNA sequence data (Excoffier et al. 1992) to determine the degree of genetic differentiation between all pairs of sample collections. To test different hypothetical scenarios, the variation attributed to differences among groups $\left(\Phi_{\mathrm{CT}}\right)$, among populations within each group $\left(\Phi_{\mathrm{SC}}\right)$ and among all populations (overall $\Phi_{\mathrm{ST}}$ ) were estimated using a Molecular Variance Analysis (AMOVA) (Excoffier et al. 1992). We tested four distinct scenarios using the sample collections groupings North (ANE, EE1, EW), South (ASE, ASW, EE2), East (ANE, EE1, EE2, ASE), West (ASW, EW) and Indian Ocean (ISW) and another one considering all samples as a single group. Two simulations were made considering differences between hemispheres: North vs. (South + Indian) and North vs. South vs.
Indian Ocean. Regarding the East and West Atlantic portions, we conducted two other simulations: East vs. (West + Indian Ocean) and East vs. West vs. Indian Ocean. The AS and ANW sample collections was excluded from AMOVA due to small sample size (3 individuals). The pairwise $\Phi_{\mathrm{ST}}$ and AMOVA were calculated using the software ARLEQUIN 3.5.1.3 (Excoffier and Lischer 2010) following the evolutionary model of Tamura and Nei (1993); the statistical significance was determined by non-parametric tests with 10,000 permutations under sequential Bonferroni corrections (Rice 1989).

We applied the Tajima's D (Tajima 1989) and Fu's $\mathrm{F}_{\mathrm{S}}$ neutrality tests ( $\mathrm{Fu}$ 1997) to investigate the deviation of the neutrality expectations in A. superciliosus and to infer the demographic pattern using the Arlequin 3.5 software (Excoffier and Lischer 2010).

\section{Results}

In the present study, we used 858 base pairs from the mtDNA CR of 228 A. superciliosus individuals, covering about $80 \%$ of the CR described for this species by Chang et al. (2014). Sequences of all haplotypes were deposited in the GenBank (Accession Nos. MF069493-MF069502). The DNA sequence was composed of Adenine $=31.94 \%$, Thymine $=$ $32.53 \%$, Cytosine $=22.02 \%$ and Guanine $=13.52 \%$.

A total of ten haplotypes (As1-As10) was generated from 14 segregating sites, with 5 transitions and 10 transversions (Table 1). Among the haplotypes, As1 was the most frequently found, widely distributed, and represented by 217 individuals $(93.5 \%)$. The nine remaining haplotypes presented low frequencies, with a maximum of $1.3 \%$ (Fig. 1, Table 1).

The nucleotide diversity was notably low ( $\pi=0.00118 \pm 0.00089$ ) and so was the corresponding haplotype diversity $(h=0.127 \pm 0.030)$ (Table 2). Two haplogroups with eight mutations among them were formed in the network (Fig. 2). Using haplotype-based Neighbor-joining tree it is possible to identify two lineages exhibiting bootstrap scores of 73 and $99 \%$ (based on 1000 replicates) for Lineage A and Lineage B, respectively. These two lineages correspond to the two haplogroups detected within the haplotype network and are indicated as Lineage A (As1, As2, As3, As4 haplotypes) and Lineage B (As5, As6, As7, As8, As9, As10 
Table 1 Position in base pairs of polymorphic sites of the CR from Alopias superciliosus samples and number of individuals per haplotype and their geographical distribution

\begin{tabular}{|c|c|c|c|c|c|c|c|c|c|c|c|c|c|c|c|c|c|c|c|c|c|c|c|}
\hline \multirow[b]{2}{*}{ Hap } & \multicolumn{14}{|c|}{ Polymorphic sites (1-858) } & \multicolumn{9}{|c|}{ Samples for groups and haplotypes } \\
\hline & 0 & 0 & 1 & 1 & 1 & 2 & 2 & 2 & 2 & 3 & 4 & 6 & 7 & 8 & & & & & & & & & \\
\hline & 4 & 6 & 7 & 9 & 9 & 0 & 0 & 5 & 5 & 8 & 1 & 8 & 7 & 3 & ANE & EE1 & EE2 & ASE & AS & EW & ASW & ANW & ISW \\
\hline & 9 & 6 & 8 & 5 & 7 & 3 & 9 & 4 & 6 & 1 & 8 & 7 & 5 & 6 & (74) & (23) & (51) & (26) & (3) & (19) & (13) & (3) & (16) \\
\hline As1 & $\mathrm{C}$ & $\mathrm{T}$ & $\mathrm{T}$ & $\mathrm{T}$ & A & A & A & G & $\mathrm{T}$ & A & $\mathrm{C}$ & $\mathrm{C}$ & A & $\mathrm{C}$ & 71 & 22 & 46 & 25 & 2 & 18 & 13 & 2 & 14 \\
\hline As 2 & . & . & . & . & . & . & . & . & . & . & . & $\mathrm{T}$ & $\mathrm{T}$ & $\mathrm{T}$ & 1 & - & - & - & - & - & - & 1 & - \\
\hline As3 & $\mathrm{G}$ & $\mathrm{C}$ & $\mathrm{C}$ & A & $\mathrm{T}$ & $\mathrm{T}$ & . & A & A & $\mathrm{T}$ & A & . & . & . & - & 1 & - & - & - & - & - & - & - \\
\hline As4 & . & . & . & . & . & . & . & . & . & . & . & $\mathrm{T}$ & . & . & - & - & - & - & - & 1 & - & - & 2 \\
\hline As5 & . & . & . & . & $\mathrm{T}$ & . & . & . & . & . & . & . & . & . & 1 & - & - & - & - & - & - & - & - \\
\hline As6 & $\mathrm{G}$ & $\mathrm{C}$ & $\mathrm{C}$ & A & $\mathrm{T}$ & . & $\mathrm{T}$ & A & A & $\mathrm{T}$ & A & . & . & . & - & - & 1 & - & - & - & - & - & - \\
\hline As7 & $\mathrm{G}$ & $\mathrm{C}$ & $\mathrm{C}$ & A & $\mathrm{T}$ & . & $\mathrm{T}$ & A & A & $\mathrm{T}$ & A & $\mathrm{T}$ & $\mathrm{T}$ & $\mathrm{T}$ & - & - & 1 & 1 & 1 & - & - & - & - \\
\hline As8 & $\mathrm{G}$ & $\mathrm{C}$ & $\mathrm{C}$ & A & $\mathrm{T}$ & . & . & A & A & $\mathrm{T}$ & A & $\mathrm{T}$ & $\mathrm{T}$ & $\mathrm{T}$ & - & - & 1 & - & - & - & - & - & - \\
\hline As 9 & $\mathrm{G}$ & $\mathrm{C}$ & $\mathrm{C}$ & A & $\mathrm{T}$ & . & . & A & A & $\mathrm{T}$ & A & . & $\mathrm{T}$ & $\mathrm{T}$ & - & - & 1 & - & - & - & - & - & - \\
\hline As10 & $\mathrm{G}$ & $\mathrm{C}$ & A & A & $\mathrm{T}$ & $\mathrm{T}$ & . & A & A & $\mathrm{T}$ & A & $\mathrm{T}$ & $\mathrm{T}$ & $\mathrm{T}$ & 1 & - & 1 & - & - & - & - & - & - \\
\hline
\end{tabular}

The letters indicate nucleotides and the points indicate no change of base, relative to the first listed haplotype (As1)

Table 2 Genetic diversity indices for each location for Alopias superciliosus
Standard deviation (SD), haplotype diversity $(h)$, nucleotide diversity $(\pi)$

\begin{tabular}{lllll}
\hline Population & Haplotype diversity $h$ & SD & Nucleotide diversity $\pi(\%)$ & SD $(\%)$ \\
\hline EE1 & 0.087 & 0.078 & 0.010 & 0.020 \\
EE2 & 0.188 & 0.074 & 0.205 & 0.132 \\
ASE & 0.077 & 0.070 & 0.111 & 0.086 \\
AS & 0.667 & 0.314 & 0.960 & 0.763 \\
ANE & 0.080 & 0.043 & 0.077 & 0.065 \\
EW & 0.105 & 0.092 & 0.116 & 0.090 \\
ASW & 0.000 & 0.000 & 0.000 & 0.000 \\
ANW & 0.667 & 0.314 & 0.220 & 0.207 \\
ISW & 0.233 & 0.126 & 0.258 & 0.166 \\
Total & 0.127 & 0.030 & 0.118 & 0.088 \\
Lineage A & 0.054 & 0.021 & 0.011 & 0.021 \\
Lineage B & 0.889 & 0.091 & 0.317 & 0.211 \\
\hline
\end{tabular}

haplotypes) (Fig. 2). Lineage B is found in 3.9\% of the samples and regarded as rare. The genetic distance between the two lineages was $0.012 \pm 0.003$.

The pairwise $\Phi_{\mathrm{ST}}$ values (Table S1) were negative and/or non-significant $(p>0.05)$, failing to support the existence of population structure. Likewise, the results of the molecular variance analysis (AMOVA) did not reveal significant differences in any of the cases of simulations of population structuring (Table 3), even when comparing pairs from the Atlantic and Indian Oceans. The overall $\Phi_{\mathrm{ST}}$ value was $0.00727(p=0.25713 \pm 0.00491)$, thus not rejecting a null hypothesis of panmixia.

Based on AMOVA results, all sampling sites were combined as a single group for analyses of population expansions. Considering all samples as a single population, the non-significant values of the Tajima's D and Fu's $F_{S}$ tests (Table 4) did not corroborate a recent population expansion. Since we found evidence of two haplogroups, we also conducted neutrality tests for each lineage separately. Significant negative values of Tajima's D and Fu's $F_{S}$ (Table 4) suggest a sudden population expansion on Lineage A. 

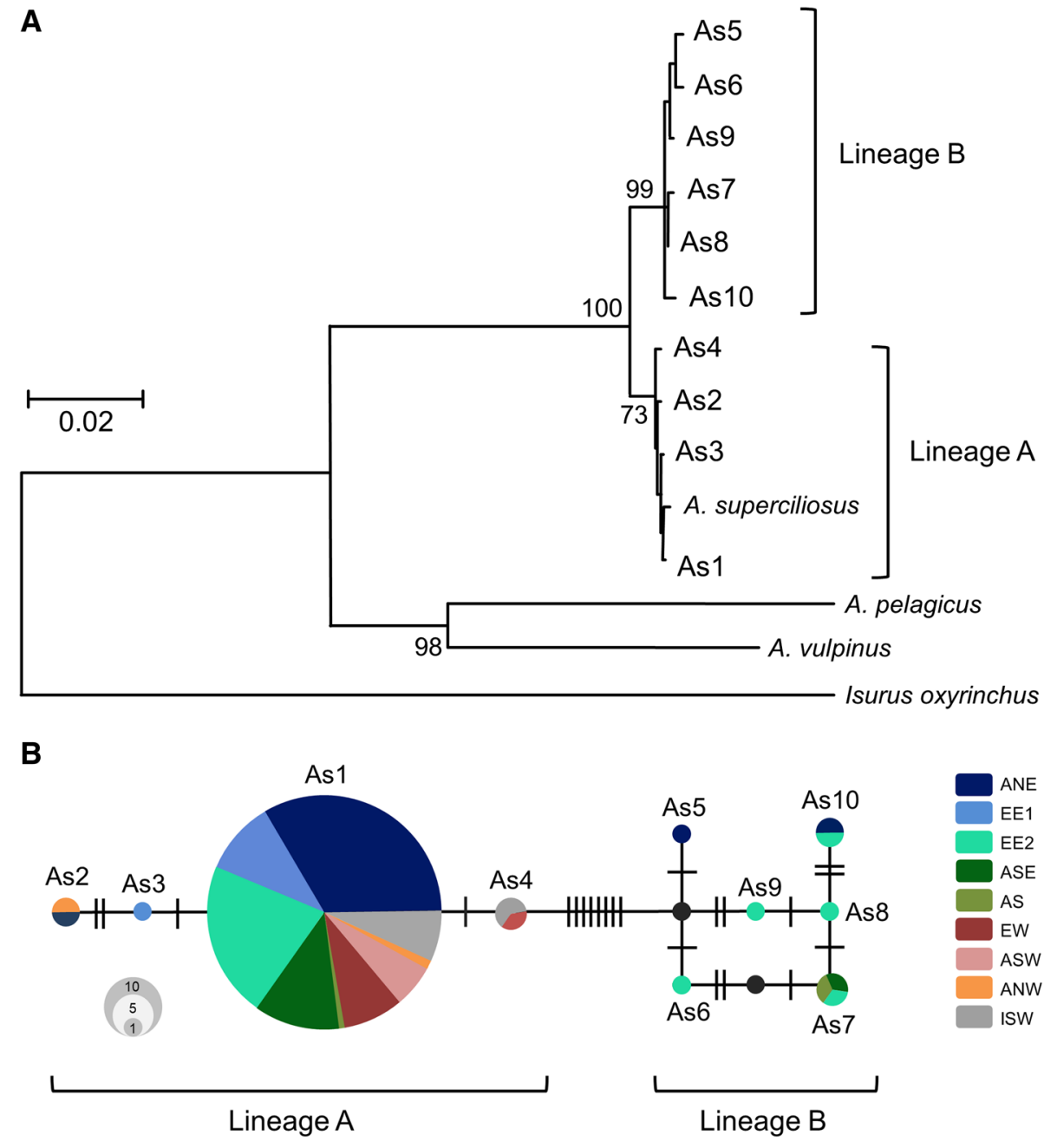

Isurus oxyrinchus

Fig. 2 A. Neighbor-Joining tree of haplotypes generated using Tamura-Nei distances. The two haplogroups are indicated as Lineage A and Lineage B. Percentages of bootstrap are shown when $>50 \%$ (in 1000 replicates). As1-10 indicate the haplotypes found. B. Haplotype network for Alopias superciliosus. Colored circles represent observed haplotypes except black

Otherwise, the values of Tajima's D and Fu's $F_{S}$ were also non-significant for Lineage $B$, which do not support the notion of a recent population expansion of this lineage.

\section{Discussion}

Genetic diversity and population structure

Among the genetic studies already performed in elasmobranchs, the detection of low genetic diversity circles which represent inferred (not observed) haplotypes. Circle size is proportional to haplotype frequency in the whole sample and colors indicate locations where each haplotype was found. Number of mutations between haplotypes is indicated by black vertical bars

is not unusual (e.g. Schultz et al. 2008; Pereyra et al. 2010; Karl et al. 2011; Portnoy et al. 2014; Andreotti et al. 2016; Camargo et al. 2016). In a previous global study using mtDNA CR, Alopias superciliosus presented the lowest genetic diversity among the three species of the genus (Trejo 2005). Considering only the Atlantic Ocean, Trejo analyzed 17 individuals and all shared the same haplotype. The low genetic diversity values we found are in line with the results of Trejo (2005), but, due to a larger and more comprehensive sampling performed in the present study, it was possible to identify rare haplotypes. In 
Table 3 Analysis of molecular variance for five distinct scenarios of population structure

\begin{tabular}{|c|c|c|c|c|c|}
\hline Source of variation & $\begin{array}{l}\text { Degrees of } \\
\text { freedom }\end{array}$ & $\begin{array}{l}\text { Sum of } \\
\text { squares }\end{array}$ & $\begin{array}{l}\text { Variance } \\
\text { components }\end{array}$ & $\begin{array}{l}\text { Percentage of } \\
\text { variation }\end{array}$ & Fixation indices ( $p$ value) \\
\hline \multicolumn{6}{|l|}{ All } \\
\hline Among populations & 6 & 3.261 & 0.00327 & 0.73 & \multirow[t]{3}{*}{$\Phi_{\mathrm{ST}}=0.007(p=0.257)$} \\
\hline Within populations & 215 & 96.130 & 0.44712 & 99.27 & \\
\hline Total & 221 & & & & \\
\hline \multicolumn{6}{|c|}{ North vs. (South + Indian Ocean) } \\
\hline Among groups & 1 & 0.986 & 0.005 & 1.050 & $\Phi_{\mathrm{CT}}=0.010(p=0.315)$ \\
\hline $\begin{array}{l}\text { Among populations within } \\
\text { groups }\end{array}$ & 5 & 2.275 & 0.000 & 0.070 & $\Phi_{\mathrm{SC}}=0.001(p=0.486)$ \\
\hline Within populations & 215 & 96.130 & 0.447 & 98.880 & $\Phi_{\mathrm{ST}}=0.011(p=0.253)$ \\
\hline Total & 221 & 99.391 & 0.452 & & \\
\hline \multicolumn{6}{|c|}{ North vs. South vs. Indian Ocean } \\
\hline Among groups & 2 & 1.639 & 0.007 & 1.500 & $\Phi_{\mathrm{CT}}=0.015(p=0.188)$ \\
\hline $\begin{array}{l}\text { Among populations within } \\
\text { groups }\end{array}$ & 4 & 1.622 & -0.001 & -0.330 & $\Phi_{\mathrm{SC}}=-0.003(p=0.593)$ \\
\hline Within populations & 215 & 96.130 & 0.447 & 98.830 & $\Phi_{\mathrm{ST}}=0.012(p=0.254)$ \\
\hline Total & 221 & 99.391 & 0.452 & & \\
\hline \multicolumn{6}{|c|}{ West vs. (East + Indian Ocean) } \\
\hline Among groups & 1 & 0.522 & 0.000 & 0.020 & $\Phi_{\mathrm{CT}}=0.000(p=0.526)$ \\
\hline $\begin{array}{l}\text { Among populations within } \\
\text { groups }\end{array}$ & 5 & 2.739 & 0.003 & 0.720 & $\Phi_{\mathrm{SC}}=0.007(p=0.236)$ \\
\hline Within populations & 215 & 96.130 & 0.447 & 99.260 & $\Phi_{\mathrm{ST}}=0.007(\mathrm{p}=0.261)$ \\
\hline Total & 221 & 99.391 & 0.450 & & \\
\hline \multicolumn{6}{|l|}{ West vs. East vs. Indian Ocean } \\
\hline Among groups & 2 & 0.938 & -0.001 & -0.320 & $\Phi_{\mathrm{CT}}=-0.003(p=0.563)$ \\
\hline $\begin{array}{l}\text { Among populations within } \\
\text { groups }\end{array}$ & 4 & 2.323 & 0.004 & 0.870 & $\Phi_{\mathrm{SC}}=0.009(p=0.213)$ \\
\hline Within populations & 215 & 96.130 & 0.447 & 99.450 & $\Phi_{\mathrm{ST}}=0.006(p=0.262)$ \\
\hline Total & 221 & 99.391 & 0.450 & & \\
\hline
\end{tabular}

Table 4 Neutrality tests

\begin{tabular}{lllll}
\hline & Tajima's & $p$ value & Fu's F & $p$ value \\
& $\mathrm{D}$ & & & \\
\hline $\begin{array}{c}\text { Single } \\
\text { population }\end{array}$ & -1.4149 & 0.0501 & -2.8316 & 0.1490 \\
Lineage A & -1.5191 & 0.0164 & -4.1682 & 0.0048 \\
Lineage B & 1.0170 & 0.8627 & -1.3946 & 0.1403 \\
\hline
\end{tabular}

addition to the low nucleotide diversity, the haplotype diversity found is among the lowest for mtDNA CR in elasmobranchs (Schultz et al. 2008; Pereyra et al.
2010; Portnoy et al. 2010; Phillips et al. 2011; Karl et al. 2012; Li et al. 2015; Clarke et al. 2015; Ferrette et al. 2015; Bernard et al. 2016, 2017; Domingues et al. 2017).

Non-significant and negative values of $\Phi_{\mathrm{ST}}$ were identified in all analyses conduced to evaluate the population structure among the sample collections of the A. superciliosus. The existence of these values, which do not allow rejection of the null hypothesis of panmixia in the sampled area, demonstrate a possible absence of population structure of the species within the Atlantic Ocean and between the Atlantic and Indian Oceans. Additionally, in the Analysis of Molecular Variance, signals of structured populations 
in the Atlantic and Indian Oceans were not detected, even when considering various simulations in terms of hypothetical scenarios of differentiation. However, the magnitude and patterns of population genetic structure are different between species of the genus Alopias (Trejo, 2005). Cardeñosa et al. (2014) observed a strong population structure between Eastern and Western Pacific in A. pelagicus with sampling of 351 individuals captured at six different locations across the Pacific Ocean, using seven microsatellite loci and mitochondrial COI gene.

Some pelagic species of sharks and teleost fish have the ability to migrate long distances. In studies on highly migratory oceanic pelagic teleost species such as the Thunnus obesus (Martinez et al. 2006), Makaira nigricans (McDowell et al. 2007), and Tetrapturus albidus (Graves and McDowell 2006), a lack of population structure was reported in the Atlantic Ocean. Studies on pelagic species of elasmobranchs have also demonstrated the occurrence of weak or absent population structure in this region, such as Cetorhinus maximus (Hoelzel et al. 2006) and Pseudocarcharias kamoharai (Ferrette et al. 2015). Contrastingly, studies on two other pelagic elasmobranch species reported different results in population genetic structure. White sharks (Carcharodon carcharias) of the northwestern Atlantic and southern Africa present significant population structure, and three genetically distinct lineages distributed globally (O'Leary et al. 2015; Andreotti et al. 2016). For the oceanic whitetip shark (Carcharhinus longimanus) a population structure $\left(\Phi_{\mathrm{ST}}=0.1039, p<0.001\right)$ was observed between populations of the eastern and western regions of the Atlantic (Camargo et al. 2016). Both C. carcharias and $C$. longimanus present a high migratory capacity. However, for these two species it was suggested that the patterns of population structure occur due to the female philopatry (Compagno 1984, 2001; Camargo et al. 2016). Our results do not show evidence of this behavior in A. superciliosus.

Although we did not detect the existence of population structure among the samples collected in different regions in the Atlantic, the analyses revealed the existence of two lineages (Fig. 2), with a genetic distance of $0.012 \pm 0.003$ between them. One of these lineages can be considered rare (approximately 3.9\% of individuals) and was found only in eastern Atlantic. However, there is a possibility that the rare haplotypes of Lineage B were not detected in western locations due to the sampling bias. Thus, the possibility of the occurrence of individuals of Lineage B throughout the Atlantic Ocean should be considered.

The presence of two well-defined lineages along the Atlantic Ocean has also been identified in some pelagic species with a similar distribution to that of the bigeye thresher shark, such as Thunnus obesus (Martínez et al., 2006) and Lepidocybium flavobrunneum (Brendtro et al. 2008). Martínez et al. (2006) and Brendtro et al. (2008) reported the existence of one genetic lineage exclusive from Atlantic Ocean and a second one shared with the Indo-Pacific. These studies proposed that the Benguela Upwelling System may have isolated the Atlantic population, but sporadic heating events allowed a one-way migration of individuals from the Indo-Pacific to the Atlantic Ocean for their respective studied species (Martínez et al. 2006; Brendtro et al. 2008).

The low temperatures in the Africa southern region do not seem to represent a barrier to the migration of Alopias superciliosus between Atlantic and IndoPacific regions. This hypothesis is supported by the ecological data for this species, that show a displacement of $1.125 \mathrm{~km}$ in 27 days (Weng and Block 2004), the ability to live in temperatures ranging from 4 to $26{ }^{\circ} \mathrm{C}$ (Nakano et al. 2003; Weng and Block 2004), and observations by fishing vessels which record the occurrence of the species in the South African region close to the Western Cape in the Atlantic Ocean, as well as in the provinces of the Eastern Cape and Kwazulu-Natal, Indian Ocean (Compagno 2001; Petersen et al. 2009). Our data also support this hypothesis as individuals sampled between SE Africa and Madagascar have the same haplotype (As1), as more than $90 \%$ of the bigeye thresher sharks of the Atlantic, including individuals from Florida, USA.

In a previous study with 64 individuals of $A$. superciliosus, genetic structure between the Atlantic population and all populations in the Pacific was reported based on pairwise $\Phi_{\mathrm{ST}}$ tests, but no overall genetic structure was detected in the AMOVA (Trejo 2005). The single haplotype found in the Atlantic Ocean by Trejo (2005) was also shared with part of the individuals from the Pacific populations, including individuals from the Indian Ocean near South Africa. Similarly, the sequence of A. superciliosus presented by Chang et al. (2014), from samples obtained in the Pacific Ocean near Taiwan, shows a correspondence with Lineage A, widely distributed in the all sampled 
areas and includes $96.1 \%$ of the individuals analyzed. In addition to the high dispersion capacity, it is possible that the dominant presence of Lineage A in the Atlantic Ocean is due to a founder effect.

Concerning Lineage A, the negative and significant values of Tajima's D and Fu's $F_{S}$ suggest a sudden population expansion. The coexistence of another mitochondrial lineage (Lineage B) may be due to a secondary contact. This secondary contact might have happened after an isolation period between groups of individuals which, as a consequence, may have caused the genetic differentiation between both lineages which have currently become admixed. Thus, explaining the lack of detection of haplotype frequency differences between the sample collections analyzed. Two alternative hypotheses could explain the genetic distance between these lineages: (1) An isolation between lineages in Atlantic and Indo-Pacific followed by secondary contact, or (2) A previous isolation and subsequent admixture inside the Indopacific, followed by an Atlantic colonization by both lineages. Which of these hypotheses supports this pattern remains to be tested. Further studies using more samples from Indo-Pacific may elucidate the evolutionary history of the bigeye thresher shark.

\section{Implications for conservation}

Fundamental aspects in the search for sustainable use of marine resources are the identification and maintenance of distinct stocks and the preservation of genetic variability. These also serve as basic objectives in management and conservation programs. In the present study, these aspects were approached for the bigeye thresher shark A. superciliosus by analyzing the mtDNA control region, one of the most widely used methodologies for vertebrates, including sharks (e.g., Hoelzel et al. 2006; Karl et al. 2011; Mendonça et al. 2011; Dudgeon et al. 2012; Clarke et al. 2015; Camargo et al. 2016; Veríssimo et al. 2017). The scenario identified for the bigeye thresher shark warrants caution.

The low genetic variability found for the $A$. superciliosus may represent a dramatic risk to the adaptive potential of the species leading to a weaker ability to respond to environmental changes, promoting extinction of vulnerable lineages in a short time. The identification of two distinct lineages occurring in sympatry for A. superciliosus, with one of them probably being represented by a very small number of individuals and that can occur all over Atlantic Ocean leads us to recommend urgency in adopting measures for protection of the genetic diversity in this species. As the results show the absence of population structure throughout the Atlantic, and between the Atlantic and Indian Oceans, even in the total analysis with the two lineages, we propose that the species A. superciliosus constitutes a single population with high gene flow in the Atlantic Ocean.

Considering the movement of individuals between the Indian and Atlantic oceans, the absence of any significant geographic population structure can be an indication that there is only one population stock throughout the sampled area. However, despite the evidence of the possible absence of physical barriers to gene flow across a wide area of the Atlantic Ocean and part of the Indian Ocean, we note the presence of a second rare lineage that can be found in all over Atlantic Ocean. The results indicate that effective strategies for the management of A. superciliosus require attention and cooperation both regionally and internationally. This species has an exceptionally low genetic diversity and few individuals genetically heterogeneous. Management plans for the conservation of the species across the Atlantic Ocean should be devised, as individuals from lineages with greater genetic diversity (Lineage B) are not found in large scale in any particular area.

Acknowledgements The authors thank all those who contributed with this study, including anonymous reviewers. Sampling from the Portuguese fishery in the Atlantic and Indian Oceans was conducted by the Portuguese Institute for the Ocean and Atmosphere (IPMA), Portugal, within the scope of the European Data Collection Framework (PNAB/DCF). Thanks are also due to the technicians from IPMA for collecting and carefully handling samples during the Portuguese pelagic longline fishery observer program. R. Coelho is supported by an Investigador-FCT contract from the Portuguese Foundation for Science and Technology (FCT, Fundação para a Ciência e Tecnologia) supported by the EU European Social Fund and the Programa Operacional Potencial Humano (Ref: IF/00253/ 2014). This work was funded by FAPESP (Ref: BIOTA 2011/23787-0) and Project THRESHER (funded by FCT, Ref: PTDC/MAR/109915/2009).

\section{References}

Amorim A, Baum J, Cailliet GM, Clò S, Clarke SC, Fergusson I, Gonzalez M, Macias D, Mancini P, Mancusi C, Myers R, 
Reardon M, Trejo T, Vacchi M, Valenti SV (2009) Alopias superciliosus. In: IUCN 2011. IUCN red list of threatened species. Version 2011.2. http://www.iucnredlist.org/apps/ redlist/details/161696/0. Accessed 22 May 2016

André C, Larsson LC, Laikre L, Bekkevold D, Brigham J, Carvalho GR, Dahlgren TG, Hutchinson WF, Mariani S, Mudde K, Ruzzante DE, Ryman N (2011) Detecting population structure in a high gene-flow species, Atlantic herring (Clupea harengus): direct, simultaneous evaluation of neutral vs putatively selected loci. Heredity 106(2):270-280

Andreotti S, Heyden S, Henriques R, Rutzen M, Meÿer M, Oosthuizen H, Matthee CA (2016) New insights into the evolutionary history of white sharks, Carcharodon carcharias. J Biogeogr 43(2):328-339

Bandelt HJ, Forster P, Röhl A (1999) Median-joining networks for inferring intraspecific phylogenies. Mol Biol Evol 16(1):37-48

Bernard AM, Feldheim KA, Heithaus MR, Wintner SP, Wetherbee BM, Shivji MS (2016) Global population genetic dynamics of a highly migratory, apex predator shark. Mol Ecol 25(21):5312-5329

Bernard AM, Horn RL, Chapman DD, Feldheim KA, Garla RC, Brooks EJ, Gore MA, Shivji MS (2017) Genetic connectivity of a coral reef ecosystem predator: the population genetic structure and evolutionary history of the Caribbean reef shark (Carcharhinus perezi). J Biogeogr 44(11):2488-2500

Brendtro KS, McDowell JR, Graves JE (2008) Population genetic structure of escolar (Lepidocybium flavobrunneum). Mar Biol 155(1):11-22

Camargo SM, Coelho R, Chapman D, Howey-Jordan L, Brooks EJ, Fernando D, Mendes NJ, Hazin FHV, Oliveira C, Santos MN, Foresti F, Mendonça FF (2016) Structure And genetic variability of the oceanic whitetip shark, Carcharhinus longimanus, determined using mitochondrial DNA. PLoS ONE 11(5):e0155623. https://doi.org/10. 1371/journal.pone.0155623

Camhi MD, Pikitch EK, Babcock EA (2008) Methods to improve understanding of pelagic sharks: demographics, assessment, and stock structure. In: Camhi MD, Pikitch EK, Babcock EA (eds) Sharks of the open ocean: biology, fisheries and conservation. Blackwell Publishing, Oxford, pp 285-287

Camhi MD, Valenti SV, Fordham SV, Fowler SL, Gibson C (2009) The conservation status of pelagic sharks and rays: report of the IUCN shark specialist group pelagic shark red list workshop. IUCN Species Survival Commission Shark Specialist Group, Newbury

Cardeñosa D, Hyde J, Caballero S (2014) Genetic diversity and population structure of the pelagic thresher shark (Alopias pelagicus) in the Pacific Ocean: evidence for two evolutionarily significant units. PLoS ONE 9(10):e110193. https://doi.org/10.1371/journal.pone.0110193

Chang CH, Shao KT, Lin YS, Ho HC, Liao YC (2014) The complete mitochondrial genome of the big-eye thresher shark, Alopias superciliosus (Chondrichthyes, Alopiidae). Mitochondrial DNA 25(4):290-292

Chen CT, Liu KM, Chang YC (1997) Reproductive biology of the bigeye thresher shark, Alopias superciliosus (Lowe,
1839) (Chondrichthyes: Alopiidae), in the northwestern Pacific. Ichthyol Res 44(2-3):227-235

Clarke CR, Karl SA, Horn RL, Bernard AM, Lea JS, Hazin FH, Prodöhl PA, Shivji MS (2015) Global mitochondrial DNA phylogeography and population structure of the silky shark, Carcharhinus falciformis. Mar Biol 162(5):945-955

Coelho R, Fernandez-Carvalho J, Lino PG, Santos MN (2012) An overview of the hooking mortality of elasmobranchs caught in a swordfish pelagic longline fishery in the Atlantic Ocean. Aquat Living Res 25(04):311-319

Compagno LJV (1984) FAO species catalogue, vol 4. Sharks of the world. An annotated and illustrated catalogue of shark species known to date. Part 2-Carcharhiniformes. FAO Fish Synop 125(4/2):251-655. FAO, Rome

Compagno LJV (2001) Sharks of the world. An annotated and illustrated catalogue of shark species known to date. Bullhead, mackerel and carpet sharks (Heterodontiformes, Lamniformes and Orectolobiformes). In: FAO species catalogue for fishery purposes, vol 2. FAO, Rome

Cortés E, Arocha F, Beerkircher L, Carvalho F, Domingo A, Heupel M, Holtzhausen H, Santos MN, Ribera M, Simpfendorfer C (2010) Ecological risk assessment of pelagic sharks caught in Atlantic pelagic longline fisheries. Aquat Living Res 23(1):25-34

Domingues RR, Hilsdorf AW, Shivji MM, Hazin FV, Gadig OB (2017) Effects of the Pleistocene on the mitochondrial population genetic structure and demographic history of the silky shark (Carcharhinus falciformis) in the western Atlantic Ocean. Rev Fish Biol Fish. https://doi.org/10. 1007/s11160-017-9504-z

Dudgeon CL, Blower DC, Broderick D, Gile JL, Holmes BJ, Kashiwagi T, Krück NC, Morgan AT, Tillet BJ, Ovenden JR (2012) A review of the application of molecular genetics for fisheries management and conservation of sharks and rays. J Fish Biol 80(5):1789-1843

Excoffier L, Lischer HE (2010) Arlequin suite ver 3.5: a new series of programs to perform population genetics analyses under Linux and Windows. Mol Ecol Res 10(3):564-567

Excoffier L, Smouse PE, Quattro JM (1992) Analysis of molecular variance inferred from metric distances among DNA haplotypes: application to human mitochondrial DNA restriction data. Genetics 131(2):479-491

Fernandez-Carvalho J, Coelho R, Mejuto J, Cortés E, Domingo A, Yokawa K, Liu K-M, García-Cortés B, Forselledo R, Ohshimo S, Ramos-Cartelle A, Tsai W-P, Santos NM (2015a) Pan-Atlantic distribution patterns and reproductive biology of the bigeye thresher, Alopias superciliosus. Rev Fish Biol Fish 25:551-568

Fernandez-Carvalho J, Coelho R, Erzini K, Santos MN (2015b) Modeling age and growth of the bigeye thresher (Alopias superciliosus) in the Atlantic Ocean. Fish B-NOAA 113:468-481

Ferrette BLS, Mendonça FF, Coelho R, de Oliveira PGV, Hazin FHV, Romanov EV, Oliveira C, Santos MN, Foresti F (2015) High connectivity of the crocodile shark between the Atlantic and Southwest Indian Oceans: highlights for conservation. PLoS ONE 10(2):1-10

Fu Y-X (1997) Statistical tests of neutrality of mutations against population growth, hitchhiking and background selection. Genetics 147(2):915-925 
Graves JE, McDowell JR (2006) Genetic analysis of white marlin (Tetrapturus albidus) stock structure. Bull Mar Sci 79(3):469-482

Hoelzel AR, Shivji MS, Magnussen J, Francis MP (2006) Low worldwide genetic diversity in the basking shark ( $\mathrm{Ce}$ torhinus maximus). Biol Lett 2(4):639-642

ICCAT (2013) Report of the inter-sessional meeting of the sharks species group. Mindelo, Cape Verde, 81 pp, 8-12 Apr 2013

Ivanova NV, Dewaard JR, Hebert PD (2006) An inexpensive, automation-friendly protocol for recovering high-quality DNA. Mol Ecol Notes 6(4):998-1002

Karl SA, Castro ALF, Lopez JA, Charvet P, Burgess GH (2011) Phylogeography and conservation of the bull shark (Carcharhinus leucas) inferred from mitochondrial and microsatellite DNA. Conserv Genet 12(2):371-382

Karl SA, Castro AL, Garla RC (2012) Population genetics of the nurse shark (Ginglymostoma cirratum) in the western Atlantic. Mar Biol 159(3):489-498

Kearse M, Moir R, Wilson A, Stones-Havas S, Cheung M, Sturrock S et al (2012) Geneious basic: an integrated and extendable desktop software platform for the organization and analysis of sequence data. Bioinformatics 28:1647-1649

Keeney DB, Heist EJ (2006) Worldwide phylogeography of the blacktip shark (Carcharhinus limbatus) inferred from mitochondrial DNA reveals isolation of western Atlantic populations coupled with recent Pacific dispersal. Mol Ecol 15(12):3669-3679

Li N, Chen X, Sun D, Song N, Lin Q, Gao T (2015) Phylogeography and population structure of the red stingray, Dasyatis akajei inferred by mitochondrial control region. Mitochondrial DNA 26(4):505-513

Liu KM, Chiang PJ, Chen CT (1998) Age and growth estimates of the bigeye thresher shark, Alopias superciliosus, in northeastern Taiwan waters. Fish B-NOAA 96(3):482-491

Martínez P, González EG, Castilho R, Zardoya R (2006) Genetic diversity and historical demography of Atlantic bigeye tuna (Thunnus obesus). Mol Phylogenet Evol 39(2):404-416

Mcdowell JR, Carlsson JE, Graves JE (2007) Genetic analysis of blue marlin (Makaira nigricans) stock structure in the Atlantic Ocean. Gulf Caribb Res 19(2):75-82

Mendonça FF, Oliveira C, Gadig OBF, Foresti F (2009) Populations analysis of the Brazilian Sharpnose Shark Rhizoprionodon lalandii (Chondrichthyes: Carcharhinidae) on the São Paulo coast, Southern Brazil: inferences from mt DNA sequences. Neotrop Ichthyol 7(2):213-216

Mendonça FF, Oliveira C, Gadig OB, Foresti F (2011) Phylogeography and genetic population structure of Caribbean sharpnose shark Rhizoprionodon porosus. Rev Fish Biol Fish 21(4):799-814

Nakano H, Matsunaga H, Okamoto H, Okazaki M (2003) Acoustic tracking of bigeye thresher shark Alopias superciliosus in the eastern Pacific Ocean. Mar Ecol Prog Ser 265:255-261

O'Leary SJ, Feldheim KA, Fields AT, Natanson LJ, Wintner S, Hussey N, Shivji MS, Chapman DD (2015) Genetic diversity of white sharks, Carcharodon carcharias, in the
Northwest Atlantic and southern Africa. J Hered. https:// doi.org/10.1093/jhered/esv001

Pereyra S, García G, Miller P, Oviedo S, Domingo A (2010) Low genetic diversity and population structure of the narrownose shark (Mustelus schmitti). Fish Res 106(3):468-473

Petersen SL, Honig MB, Ryan PG, Underhill LG, Compagno LJ (2009) Pelagic shark bycatch in the tuna-and swordfishdirected longline fishery off southern Africa. Afr J Mar Sci 31(2):215-225

Phillips NM, Chaplin JA, Morgan DL, Peverell SC (2011) Population genetic structure and genetic diversity of three critically endangered Pristis sawfishes in Australian waters. Mar Biol 158(4):903-915

Portnoy DS, McDowell JR, Heist EJ, Musick JA, Graves JE (2010) World phylogeography and male-mediated gene flow in the sandbar shark, Carcharhinus plumbeus. Mol Ecol 19(10):1994-2010

Portnoy DS, Hollenbeck CM, Belcher CN, Driggers WB, Frazier BS, Gelsleichter J, Grubbs RD, Gold JR (2014) Contemporary population structure and post-glacial genetic demography in a migratory marine species, the blacknose shark, Carcharhinus acronotus. Mol Ecol 23(22):5480-5495

Rice WR (1989) Analyzing tables of statistical tests. Evolution 43(1):223-225

Schultz JK, Feldheim KA, Gruber SH, Ashley MV, McGovern TM, Bowen BW (2008) Global phylogeography and seascape genetics of the lemon sharks (genus Negaprion). Mol Ecol 17(24):5336-5348

Simpfendorfer C, Cortés E, Heupel M, Brooks E, Babcock E, Baum J, McAuley R, Dudley S, Stevens JD, Fordham S, Soldo A (2008) An integrated approach to determining the risk of overexploitation for data-poor pelagic Atlantic sharks. Expert Working Group Report, ICCAT

Tajima F (1989) Statistical method for testing the neutral mutation hypothesis by DNA polymorphism. Genetics 123(3):585-595

Tamura K, Nei M (1993) Estimation of the number of nucleotide substitutions in the control region of mitochondrial DNA in humans and chimpanzees. Mol Biol Evol 10(3):512-526

Tamura K, Stecher G, Peterson D, Filipski A, Kumar S (2013) MEGA6: molecular evolutionary genetics analysis version 6.0. Mol Biol Evol 30:2725-2729

Trejo T (2005) Global phylogeography of thresher sharks (Alopias spp.) inferred from mitochondrial DNA control region sequences. Doctoral dissertation, California State University Monterey Bay

Veríssimo A, Sampaio Í, McDowell JR, Alexandrino P, Mucientes G, Queiroz N, Silva C, Jones CS, Noble LR (2017) World without borders-genetic population structure of a highly migratory marine predator, the blue shark (Prionace glauca). Ecol Evol 7(13):4768-4781

Waples RS (1998) Separating the wheat from the chaff: patterns of genetic differentiation in high gene flow species. J Hered 89(5):438-450

Weng KC, Block BA (2004) Diel vertical migration of the bigeye thresher shark (Alopias superciliosus), a species possessing orbital retia mirabilia. Fish B-NOAA 102(1):221-229 